\title{
Multi-criteria ranking of available forms of promotional activities: a case analysis
}

\section{Вишекритеријумско рангирање расположивих облика промотивних активности: анализа случаја}

\author{
Jelena Rajković \\ University "Union Nikola Tesla", Faculty of Engineering management, Belgrade, Serbia, \\ j.rajkovic24@gmail.com \\ Jasmina Poštin \\ University "Union - Nikola Tesla", Beograd, "Faculty of management", Sremski Karlovci, Serbia, \\ famzr.edu@gmail.com \\ Marko Konjikušić \\ University "Union - Nikola Tesla", Beograd, "Faculty of management", Sremski Karlovci, Serbia, \\ markozr1979@yahoo.com

\section{Aleksandra Jagodić Rusić} \\ University "Business Academy", Faculty of economics and engineering management, Novi Sad, Serbia, \\ aleksandra@aio.rs

\section{Milan Nikolić} \\ University of Novi Sad, Technical Faculty "Mihajlo Pupin”, Zrenjanin, Serbia, \\ mikaczr@sbb.rs
}

\begin{abstract}
This paper presents an analysis of the case of multicriteria choice of promotion form for a product group, in one large retail chain. The following forms of promotion were available: commercial propaganda, personal selling, sales promotion, publicity, public relations and direct marketing. The selection was made on the basis of five criteria: the effects of a given form of promotion, the costs of a given form of promotion, the compliance of a given form of promotion with consumer preferences, the appropriateness of a given form of promotion in relation to the promotion of competition and the engagement of human resources for a given form of promotion. The problem of multicriteria analysis was solved with the VIKOR method. The initial decision table and criteria weights were determined using the expert method, in which the opinions of ten experts from the observed company were taken. In this way, subjectivity in these initial procedures is reduced. The final conclusion is that in the promotion of the analyzed product group, publicity should be used to the fullest extent possible, economic propaganda should be applied in accordance with financial possibilities, and most attention and energy should be directed towards sales promotion activities.
\end{abstract}

Keywords: Promotion forms, Multi-criteria analysis, Expert method, VIKOR method, Case analysis. JEL classification: M37, C81.

Сажетак: У овом раду приказана је анализа случаја вишекритеријумског избора облика промоције за групу производа, у једном великом трговинском ланцу. На располагању су били следећи облици промоције: привредна пропаганда, лична продаја, унапређење продаје, публицитет, односи с јавношћу и директни маркетинг. Избор је вршен на бази пет критеријума: ефекти датог облика промоције, трошкови датог облика промоције, усаглашеност датог облика промоције са преференцијама потрошача, примереност датог облика промоције, у односу на промотивно деловање конкуренције и ангажованост

\footnotetext{
Corresponding author.
} 
људских ресурса за дати облик промоције. Постављени проблем вишекритеријумске анализе решаван је помоћу методе ВИКОР. Почетна табела одлучивања и тежине критеријума одређени су помоћу експертне методе у којој су узета мишљења десет експерата из посматраног предузећа. На овај начин, смањена је субјективност у овим почетним поступцима. Коначни закључак гласи: у промоцији анализиране групе производа, публицитет треба максимално користити уколико постоји, привредну пропаганду треба примењивати у складу са финансијским могућностима, а највише пажње и енергије треба усмерити ка активностима унапређења продаје.

Кључне речи: Облици промоције, вишекритеријумска анализа, експертна метода, метода ВИКОР, анализа случаја.

JEL класификација: M37, C81.

\section{Introduction}

In today's business environment, businesses need to be more flexible and have to adapt their structures and brands faster to changing social, market and technological trends while maintaining the true nature of their company. Authenticity is the biggest capital in a situation of increasing transparency of information on the web (Kotler, Kartajaya, \& Setiawan, 2017). In the sphere of marketing, innovative marketing plays a particular role and importance (Son, Sadachar, Manchiraju, Fiore, \& Niehm, 2012; Prahalad \& Ramaswamy, 2004; Muangkhot \& Ussahawanitchakit, 2015). The key effects of innovative marketing are: increasing labor productivity, the emergence of new business models, the creation of "new" jobs, new communication systems, higher protection at work, higher competitiveness, promotion of PR and brand (Schlechtendahl, Keinert, Kretschmer, Lechler, \& Verl, 2015; Hall \& Trivin, 2018; Müller \& Däschle, 2018; Wollschlaeger, Sauter, \& Jasperneite, 2017).

However, regardless of current marketing trends, some basic dilemmas and activities in practical terms always remain. One such activity is the implementation of appropriate forms of promotion for a particular product/service or product/service group. Prior to the implementation of particular forms of promotion, it is necessary to define and consider them, and this practically means making a decision on the choice of promotion forms, which are best suited to the case.

In this paper, the problem of multicriteria analysis of available forms of promotion is solved, for the purpose of ranking and defining the most favorable actions for promotion of a certain group of products, in one domestic company. Here, because of the confidentiality of the data, it is not stated which company it is, but it can be said that it is a large retail chain. What is important is the presentation of possibilities for solving this specific, as well as other similar problems in the process of selecting and defining promotional activities in business organizations.

At the beginning, the available actions were defined, namely the following forms of promotion: 1. Commercial propaganda, 2. Personal sales, 3. Sales promotion, 4. Publicity, 5. Public relations, 6. Direct marketing (Đorđević \& Ćoćkalo, 2004; Nikolić, 2012b). Then, the criteria based on which choices are made are defined: (1) Effects of a given form of promotion, (2) Costs of a given form of promotion, (3) 
Consistency of a given form of promotion with consumer preferences, (4) Suitability of a given form of promotion, in relation to the promotional activities of competitors and (5) Human resources engagement for a given form of promotion. When defining the criteria, experts from the observed company (employed in marketing function) were consulted. They have knowledge and experience in marketing, promotional activities and public relations.

The first part of solving this practical problem is to apply the expert method. Ten experts from the observed company expressed their opinion on the decision problem. Specifically, the experts gave ratings of each available action against each criterion, and also provided their own assessment of the weights of the criteria in the model. When defining attributes in the initial decision matrix, the experts took into account some general principles of ranking of particular forms of promotion (Kotler \& Armstrong, 1996; Milisavljević, 2001; Đorđević \& Ćoćkalo, 2004), as well as their experience and the specifics of the case.

Then, the average values of each stock according to each criterion were determined as well as the average values of the criterion weights. This approach can also be understood as group decision making in parallel form (Dufner, Hiltz, Johnson, \& Czech, 1995; according to Čupić, Tummala, \& Suknović, 2001). This form of group decision-making involves the quantitative determination of the result of individual opinions, which can be done at the end of application of the method (each group member performs the procedure until the end, and then finds the resultant of these final solutions) or partially, after individual steps in the applied method (each group member do a certain phase of the method, and then find the resultant, which goes with the further calculation) (Nikolić, 2012a). The second case was used in this paper: the experts expressed opinions at the beginning, the result of these opinions (average values) was immediately found, and the further calculation was continued with the initial values thus obtained, without additional subjectivity until the end of the procedure.

The problem of multicriteria analysis was solved using the VIKOR method (Opricović, 1986; Opricović \& Tzeng, 2004). This method was chosen to solve a given case, for two reasons. First, the VIKOR method can very well take advantage of the fact that the values in the initial decision table are obtained by the expert method: it enables accurate and objective calculation with the average values thus obtained. In essence, in the VIKOR method, subjectivity exists when forming an initial decision matrix, as well as when assigning weights to criteria. These two phases are made more objective precisely by the expert method, and the further procedure contains no subjectivity. Second, the VIKOR method, as a solution, provides a set of compromise solutions. This is appropriate in this case, because it is not necessary to choose only one form of promotion: applying one form of promotion does not exclude the possibility of using other forms of promotion. It is possible that the solution involves 
several actions in the set of compromise solutions, which can be a significant guideline for reaching a final decision.

\section{Multicriteria analysis}

\subsection{Introduction to multicriteria analysis}

The complexity and complexity of business decision-making often requires a multicriteria model, that is, a multi-criteria base, as a prerequisite for objective selection and choice of alternative solutions (Radojičić \& Žižović, 1998). It is clear that the area in which strategic and other decisions are made in an enterprise generally requires the application of multicriteria decision-making methods (Nikolić, 2012a). Multi-criteria decision-making (MCDM) refers to decision-making situations when there are a number of, most often conflicting, criteria (Čupić, Tummala \& Suknović, 2001). Ranking alternatives by multiple criteria at the same time contributes to the reality of dealing with such situations.

Multicriteria analysis has been used successfully in various fields of human activity. This is evidenced by numerous references related to the diverse application of multicriteria analysis, for example: evaluating the economic performance of fishing systems (Romeo \& Marcianò, 2019), evaluating a portfolio of projects in state-owned energy companies (Hernandez-Perdomo, Mun, \& Rocco, 2017), assessment of likely future scenarios under different drivers of land use change (Martínez-Sastre, Ravera, González, López Santiago, Bidegain, \& Munda, 2017), testing the differences between Integrated Pest Management (IPM) strategies in pome fruit across Europe (Caffi, Helsen, Rossi, Holb, Strassemeyer, Buurma, Capowiez, Simon, \& Alaphilippe, 2017), identifying the highest and best use for historic buildings (Ribera, Nesticò, Cucco, \& Maselli, 2020), evaluating the sustainability of conservation agriculture (Craheix, Angevin, Doré, \& de Tourdonnet, 2016), analysis of barriers to the adoption of autonomous vehicles (Raj, Kumar, \& Bansal, 2020). It can be noted that the references are more recent, which indicates that multicriteria analysis does not in the least lose its relevance, application and importance.

\subsection{The VIKOR method}

The VIKOR (Multiple Criteria Ranking) method is a very commonly used multicriterion ranking method, suitable for solving various decision problems. In writing this point, reference has been significantly used (Nikolić, 2012a). The VIKOR method was developed based on elements from compromise programming. The method starts from the "boundary" forms of the Lp metric (Opricović, 1986). Looking for the solution closest to the ideal. The following metric is used as a measure of the distance from the ideal point: 
$\mathrm{L}_{\mathrm{p}}\left(\mathrm{F}^{*}, \mathrm{~F}\right)=\left\{\sum_{\mathrm{j}=1}^{\mathrm{n}}\left[\mathrm{f}_{\mathrm{j}}^{*}-\mathrm{f}_{\mathrm{j}}(\mathrm{x})\right]^{\mathrm{p}}\right\}^{\frac{1}{\mathrm{p}}}, \quad 1 \leq \mathrm{p} \leq \infty$

This metric represents the distance between the ideal point $\mathrm{F}^{*}$ and the point $\mathrm{F}(\mathrm{x})$ in the space of criterion functions (Opricović, 1986). Minimizing this metric determines the compromise solution. The following tags are used in the VIKOR method:

$\mathrm{m}$ - number of actions,

$\mathrm{i}$ - the ordinal number of the action, $\mathrm{i}=1,2, \ldots, \mathrm{m}$,

$\mathrm{n}$ - number of criteria,

$\mathrm{j}$ - ordinal number of criteria, $\mathrm{j}=1,2, \ldots, \mathrm{n}$,

$f_{i j}$ - the value that the ith action realizes for the $j$ th criterion function,

$\mathrm{w}_{\mathrm{j}}$ - weight of the $\mathrm{jth}$ criterion function,

$\mathrm{V}$ - the weight of the strategies to satisfy most criteria,

$\mathrm{Q}_{\mathrm{i}}$ - a measure for multi-criteria ranking of the $\mathrm{i}^{\text {th }}$ action.

For each action there is a value of Qi, and then an action is selected at which this value is the smallest (the least distance from the "ideal" point). The measure for multicriteria ranking of the ith action (Qi) is calculated by the expression:

$\mathrm{Q}_{\mathrm{i}}=\mathrm{v} \cdot \mathrm{QS}_{\mathrm{i}}+(1-\mathrm{v}) \cdot \mathrm{QR}_{\mathrm{i}}$ where is:

$\mathrm{QS}_{\mathrm{i}}=\frac{\mathrm{S}_{\mathrm{i}}-\mathrm{S}^{*}}{\mathrm{~S}^{-}-\mathrm{S}^{*}} ; \mathrm{QR}_{\mathrm{i}}=\frac{\mathrm{R}_{\mathrm{i}}-\mathrm{R}^{*}}{\mathrm{R}^{-}-\mathrm{R}^{*}}$

By calculating QSi, QRi, and Qi sizes for each action, three independent rankings can be formed. Qi size represents the establishment of a compromise ranking list combining QSi and QRi sizes. By choosing a smaller or larger value for $\mathrm{v}$, the decision maker can favor the influence of QSi size or QRi size in the compromise rankings. The labels used have the following meaning:

$$
\begin{array}{ll}
S_{i}=\sum_{j=1}^{n} w_{j} \cdot \frac{f_{j}^{*}-f_{i j}}{f_{j}^{*}-f_{j}^{-}}=\sum_{j=1}^{n} w_{j} \cdot d_{i j}, & i=1,2, \ldots, m \\
R_{i}=\max _{j} w_{j} \cdot \frac{f_{j}^{*}-f_{i j}}{f_{j}^{*}-f_{j}^{-}}=\max _{j} w_{j} \cdot d_{i j}, & i=1,2, \ldots, m \\
S^{*}=\min _{i} S_{i} ; S^{-}=\max _{i} S_{i} ; R^{*}=\min _{i} R_{i} ; R^{-}=\max _{i} R_{i}
\end{array}
$$




$$
\begin{array}{ll}
f_{j}^{*}=\max _{i} f_{i j}, & j=1,2, \ldots, n \\
f_{j}^{-}=\min _{i} f_{i j}, & j=1,2, \ldots, n .
\end{array}
$$

Action $\mathrm{a}_{\mathrm{i}}$ is better than action $\mathrm{a}_{\mathrm{k}}$, by the $\mathrm{j}^{\text {th }}$ criterion, if:

- $\mathrm{f}_{\mathrm{ij}}>\mathrm{f}_{\mathrm{kj}}$ (for max $\mathrm{f}_{\mathrm{j}}$, or when the criterion has a maximum requirement),

- $\mathrm{f}_{\mathrm{ij}}<\mathrm{f}_{\mathrm{kj}}$ (for $\min \mathrm{f}_{\mathrm{j}}$, or when the criterion has a minimum requirement)

The action ai is better than the action ak (in total, according to all criteria), if: Qi $<$ Qk. The relevant ranking list by VIKOR method is the compromise rank list for the value $\mathrm{v}=0,5$. In order for an action to be adopted as the best, according to the VIKOR method, it must be first on the compromise rank list and meet two conditions (U1 and U2).

\section{Multicriteria analysis of promotional activities by example}

\subsection{The problem of multicriteria analysis}

Defining the problem of multicriteria analysis involves identifying and adopting a list of available actions, as well as the criteria on which to make a choice. In this section, experts from the observed company were also consulted, as well as existing literature, for example (Đorđević \& Ćoćkalo, 2004; Nikolić, 2012b). The experts are employed in the marketing function of the observed company.

For the promotion of the observed product group, in the observed company, the following forms of promotion are available (these are also actions in this multicriteria analysis problem):

$a_{1}$ - Commercial propaganda. Advertising is also called economic or commercial propaganda. Propaganda is a paid means of mass communication with consumers. Economic propaganda has three main goals: to inform, persuade and remind. The key strength of propaganda is that it addresses a wide audience. According to Gordon (2011), The Institute of Practitioners in Advertising (IPA), as a professional institute for leading UK advertising agencies, defines advertising as follows: Advertising presents the most persuasive sales messages for products or services at the lowest possible cost.

$\mathbf{a}_{2}$ - Personal sale. Personal selling is a form of promotion that involves direct contact between businesses and customers. This is where the personal contact of the seller and the buyer occurs. Under such conditions, sales talk is being held and the chances of a sale being increased. The goal is to increase sales volume.

a3 - Sales promotion. Sales promotion covers all activities (except propaganda, personal selling and publicity) that further stimulate sales. These include: various 
exhibitions, presentations, exhibitions, demonstrations, sweepstakes, sales campaigns and more.

$\mathbf{a}_{4}$ - Publicity. Publicity is the publication of positive (but also negative) information about an organization, which is not funded by the company. The emphasis is on information, not persuasion. It is used to create or increase affection for the company. The main advantages of publicity (especially in relation to economic propaganda) are the following: the placement of information in the most important media, in the hit points, at the time of impact and not paid (although there are costs of preparing the material for publication).

a5 - Public relations. Generally, there are the following similarities between marketing and public relations. They: (a) deal with the organization's connections and use similar communication tools in addressing the public; (b) have the primary task of ensuring the success of the organization and its economic survival (Wilcox \& Cameron, 2009). According to the same authors, the main difference between marketing and public relations is that marketing is focused on customers and sales of products and services, and public relations takes care of building relationships and creating goodwill in public for the organization (Wilcox \& Cameron, 2009). Similarly, Grunig (1992) states a clear distinction between marketing and PR: marketing should communicate with markets related to an organization's products and services, and PR should care for all the organization's publics.

a6 - Direct marketing. Direct marketing is the direct communication with the target segments. Communication is done through various media, but the most commonly used are email, telephone and online communication over the Internet. He interacts directly with the consumer, the individual, so that he or she can talk directly through the conversation through answering questions.

The criteria on the basis of which the above actions are ranked (for promotion of the observed product group, in the observed company) are as follows:

$f_{1}$ - Effects of a given promotion form,

$\mathrm{f}_{2}$ - Cost of a given promotion (minimum requirement),

$f_{3}$ - Consistency of a given form of promotion with consumer preferences,

$\mathrm{f}_{4}$ - The suitability of a given form of promotion in relation to the promotional activities of competitors and

$f_{5}$ - Human resources engagement for a given form of promotion (minimum requirement).

\subsection{Defining Initial Decision Conditions - Expert Method}

The next step is to define the initial decision conditions. Initial decision conditions involve evaluating each action against each criterion in the model. For the given case (promotion of the observed product group, in the observed enterprise), defining the 
initial decision conditions was made by the expert test method, by having the experts express their opinions on the values of the available shares for each set criterion. The procedure involved ten experts. Qualitative assessments of the first expert (Expert 1) are given as an example in Table 1.

Table 1: Initial Decision Matrix (Expert 1)

\begin{tabular}{|c|c|c|c|c|c|}
\hline \multirow{4}{*}{$\begin{array}{c}\text { Actions } \\
\text { (promotion forms) }\end{array}$} & \multicolumn{5}{|c|}{ Criteria } \\
\hline & $\begin{array}{c}\mathrm{f}_{1}- \\
\text { Effects }\end{array}$ & $\begin{array}{c}\mathrm{f}_{2-} \\
\text { Costs }\end{array}$ & $\begin{array}{c}f_{3}- \\
\text { Consumers }\end{array}$ & $\begin{array}{c}\mathrm{f}_{4}- \\
\text { Competition }\end{array}$ & $\begin{array}{l}\mathrm{f}_{5}-\text { Hum. } \\
\text { resources }\end{array}$ \\
\hline & \multicolumn{5}{|c|}{ Request for $\max / \min$ criteria } \\
\hline & $\max$ & $\min (-)$ & $\max$ & $\max$ & $\min (-)$ \\
\hline $\mathrm{a}_{1}$ - Economic propaganda & Very High & Very High & Very High & High & Average \\
\hline $\mathrm{a}_{2}$ - Personal sales & Average & Average & Low & Average & Very High \\
\hline $\mathrm{a}_{3}$ - Sales promotion & High & Low & Average & Low & High \\
\hline $\mathrm{a}_{4}$ - Publicity & Average & very low & High & Average & Low \\
\hline a5 - Public relations & Average & High & Average & High & Average \\
\hline a6 - Direct marketing & Low & Low & Low & High & High \\
\hline
\end{tabular}

Source: the authors' research

As in Table 1, all actions are rated with qualitative ratings, it is necessary to quantify the qualitative attributes. This is done here via the interval scale (Table 2). Consideration should be given to whether there are requirements for maximization or minimization for particular criteria. In the observed case, the requirement for minimization exists on two criteria (f2 and f5). In the VIKOR method, the translation of a minimum into a maximum is performed in the next step, so quantification is performed as if all criteria had a requirement for the maximum. The initial decision matrix with such quantified attributes, for Expert 1, is given in Table 3. The initial decision matrix with quantified attributes, individually for all ten experts, is given in Table 4. The initial decision matrix with average values of quantified attributes, for all ten experts, is given in Table 5. The average values in Table 5 are divided by 10 so that the scores are in the interval $[0 ; 1]$, used in the VIKOR method.

Table 2: Interval scales for quantification of qualitative attributes

\begin{tabular}{|c|c|c|c|c|c|c|}
\hline $\begin{array}{c}\text { Qualitative } \\
\text { rating }\end{array}$ & Very Bad & Poor & Average & $\begin{array}{c}\text { Very } \\
\text { Good }\end{array}$ & Excellent & $\begin{array}{c}\text { Criteria } \\
\text { type }\end{array}$ \\
\hline $\begin{array}{c}\text { Quantitative } \\
\text { rating }\end{array}$ & 1 & 3 & 5 & 7 & 9 & $\max$ \\
\cline { 2 - 7 } & 9 & 7 & 5 & 3 & 1 & $\min$ \\
\hline
\end{tabular}

Source: (Nikolić, 2012a)

Table 3: Initial decision matrix with quantified attributes (Expert 1)

\begin{tabular}{|c|c|c|c|c|c|}
\hline \multirow{3}{*}{$\begin{array}{c}\text { Actions } \\
\text { (promotion forms) }\end{array}$} & \multicolumn{5}{|c|}{ Criteria } \\
\cline { 2 - 6 } & $\begin{array}{c}\mathrm{f}_{1}- \\
\text { Effects }\end{array}$ & $\begin{array}{c}\mathrm{f}_{2}- \\
\text { Costs }\end{array}$ & $\begin{array}{c}\mathrm{f}_{3}- \\
\text { Consumers }\end{array}$ & $\begin{array}{c}\mathrm{f}_{4}- \\
\text { Competition }\end{array}$ & $\begin{array}{c}\mathrm{f}_{5}-\text { Hum. } \\
\text { resources }\end{array}$ \\
\cline { 2 - 7 } & \multicolumn{6}{|c|}{ Request for $\max / \min$ criteria } \\
\cline { 2 - 6 } & $\max$ & $\min (-)$ & $\max$ & $\max$ & $\min (-)$ \\
\hline
\end{tabular}




\begin{tabular}{|l|l|l|l|l|l|}
\hline $\mathrm{a}_{1}$ - Economic propaganda & 9 & 9 & 9 & 7 & 5 \\
\hline $\mathrm{a}_{2}$ - Personal sales & 5 & 5 & 3 & 5 & 9 \\
\hline $\mathrm{a}_{3}$ - Sales promotion & 7 & 3 & 5 & 3 & 7 \\
\hline $\mathrm{a}_{4}$ - Publicity & 5 & 1 & 7 & 5 & 3 \\
\hline $\mathrm{a}_{5}$ - Public relations & 5 & 7 & 5 & 7 & 5 \\
\hline $\mathrm{a}_{6}$ - Direct marketing & 3 & 3 & 3 & 7 & 7 \\
\hline
\end{tabular}

Source: the authors' research

Table 4: Initial decision matrix with quantified attributes (all experts individually)

\begin{tabular}{|c|c|c|c|c|c|}
\hline \multirow{4}{*}{$\begin{array}{c}\text { Actions } \\
\text { (promotion forms) }\end{array}$} & \multicolumn{5}{|c|}{ Criteria } \\
\hline & $\begin{array}{c}f_{1}- \\
\text { Effects }\end{array}$ & $\begin{array}{c}\mathrm{f}_{2}- \\
\text { Costs }\end{array}$ & $\begin{array}{c}f_{3}- \\
\text { Consumers }\end{array}$ & $\begin{array}{c}\mathrm{f}_{4}- \\
\text { Competition }\end{array}$ & $\begin{array}{l}\mathrm{f}_{5}-\text { Hum. } \\
\text { resources }\end{array}$ \\
\hline & \multicolumn{5}{|c|}{ Request for max / min criteria } \\
\hline & $\max$ & $\min (-)$ & $\max$ & $\max$ & $\min (-)$ \\
\hline \multirow{2}{*}{$\mathrm{a}_{1}$ - Economic propaganda } & $9 ; 9 ; 7 ; 9 ; 7$ & $9 ; 7 ; 7 ; 9 ; 7$ & $9 ; 9 ; 7 ; 9 ; 7$ & $7 ; 5 ; 7 ; 7 ; 9$ & $5 ; 5 ; 7 ; 5 ; 5$ \\
\hline & $9 ; 9 ; 9 ; 9 ; 9$ & $9 ; 7 ; 7 ; 9 ; 9$ & $9 ; 9 ; 9 ; 9 ; 9$ & $7 ; 7 ; 9 ; 7 ; 7$ & $7 ; 3 ; 5 ; 5 ; 5$ \\
\hline \multirow{2}{*}{$a_{2}$ - Personal sales } & $5 ; 7 ; 5 ; 5 ; 3$ & $5 ; 7 ; 7 ; 5 ; 5$ & $3 ; 7 ; 7 ; 3 ; 3$ & $5 ; 7 ; 5 ; 5 ; 7$ & $9 ; 7 ; 7 ; 9 ; 7$ \\
\hline & $3 ; 5 ; 7 ; 5 ; 3$ & $5 ; 5 ; 7 ; 5 ; 7$ & $5 ; 3 ; 3 ; 1 ; 3$ & $3 ; 3 ; 5 ; 3 ; 7$ & $5 ; 7 ; 9 ; 7 ; 9$ \\
\hline \multirow{2}{*}{$\mathrm{a}_{3}$ - Sales promotion } & $7 ; 7 ; 5 ; 7 ; 7$ & $3 ; 5 ; 3 ; 5 ; 5$ & $5 ; 7 ; 7 ; 5 ; 3$ & $3 ; 5 ; 3 ; 3 ; 3$ & $7 ; 7 ; 7 ; 9 ; 7$ \\
\hline & $5 ; 7 ; 7 ; 5 ; 5$ & $5 ; 5 ; 3 ; 1 ; 3$ & $5 ; 5 ; 5 ; 3 ; 3$ & $5 ; 3 ; 1 ; 3 ; 5$ & $5 ; 9 ; 7 ; 5 ; 7$ \\
\hline \multirow{2}{*}{$\mathrm{a}_{4}$ - Publicity } & $5 ; 5 ; 5 ; 5 ; 5$ & $1 ; 3 ; 1 ; 5 ; 3$ & $7 ; 7 ; 5 ; 5 ; 9$ & $5 ; 3 ; 5 ; 5 ; 7$ & $3 ; 3 ; 3 ; 5 ; 3$ \\
\hline & $5 ; 3 ; 7 ; 7 ; 5$ & $3 ; 3 ; 3 ; 3 ; 3$ & $5 ; 9 ; 7 ; 7 ; 5$ & $7 ; 5 ; 3 ; 7 ; 7$ & $1 ; 5 ; 3 ; 3 ; 3$ \\
\hline \multirow{2}{*}{ a5 - Public relations } & $5 ; 3 ; 5 ; 5 ; 7$ & $7 ; 5 ; 7 ; 7 ; 9$ & $5 ; 5 ; 5 ; 3 ; 7$ & $7 ; 7 ; 3 ; 7 ; 7$ & $5 ; 5 ; 3 ; 5 ; 5$ \\
\hline & $3 ; 5 ; 5 ; 3 ; 5$ & $5 ; 7 ; 5 ; 7 ; 5$ & $3 ; 5 ; 5 ; 3 ; 5$ & $5 ; 7 ; 5 ; 7 ; 7$ & $7 ; 3 ; 1 ; 5 ; 5$ \\
\hline \multirow{2}{*}{ a6 - Direct marketing } & $3 ; 1 ; 3 ; 3 ; 3$ & $3 ; 3 ; 5 ; 3 ; 7$ & $3 ; 1 ; 5 ; 3 ; 5$ & $7 ; 7 ; 5 ; 7 ; 7$ & $7 ; 5 ; 5 ; 7 ; 7$ \\
\hline & $5 ; 3 ; 1 ; 3 ; 1$ & $5 ; 3 ; 3 ; 1 ; 3$ & $1 ; 3 ; 5 ; 1 ; 3$ & $9 ; 7 ; 5 ; 7 ; 5$ & $5 ; 3 ; 7 ; 5 ; 7$ \\
\hline
\end{tabular}

Source: the authors' research

Table 5: Initial decision matrix with average values of quantified attributes (all experts together)

\begin{tabular}{|c|c|c|c|c|c|}
\hline \multirow{4}{*}{$\begin{array}{c}\text { Actions } \\
\text { (promotion forms) }\end{array}$} & \multicolumn{5}{|c|}{ Criteria } \\
\hline & $\begin{array}{c}f_{1}- \\
\text { Effects }\end{array}$ & $\begin{array}{c}\mathrm{f}_{2}- \\
\text { Costs }\end{array}$ & $\begin{array}{c}\mathrm{f}_{3}- \\
\text { Consumers }\end{array}$ & $\begin{array}{c}\mathrm{f}_{4}- \\
\text { Competition }\end{array}$ & $\begin{array}{l}f_{5}-\text { Hum. } \\
\text { resources }\end{array}$ \\
\hline & \multicolumn{5}{|c|}{ Request for $\max / \mathrm{min}$ criteria } \\
\hline & $\max$ & $\min (-)$ & $\max$ & $\max$ & $\min (-)$ \\
\hline $\mathrm{a}_{1}$ - Economic propaganda & 0.86 & 0.80 & 0.86 & 0.72 & 0.52 \\
\hline $\mathrm{a}_{2}$ - Personal sales & 0.48 & 0.58 & 0.38 & 0.50 & 0.76 \\
\hline $\mathrm{a}_{3}$ - Sales promotion & 0.62 & 0.38 & 0.48 & 0.34 & 0.70 \\
\hline $\mathrm{a}_{4}$ - Publicity & 0.52 & 0.28 & 0.66 & 0.54 & 0.32 \\
\hline $\mathrm{a}_{5}$ - Public relations & 0.46 & 0.64 & 0.46 & 0.62 & 0.44 \\
\hline a6 - Direct marketing & 0.26 & 0.36 & 0.30 & 0.66 & 0.58 \\
\hline
\end{tabular}

Source: the authors' research

\subsection{Defining criteria weights in the model - Expert method}

The weight of the criteria in the model was also determined by the expert method. The same ten experts gave an estimate of the weights of the defined criteria. The weights of the criteria, as estimated by each expert individually, are presented in Table 6 . In the 
last row of Table 6, the average weights of each criterion were calculated according to the pattern $\Sigma / \mathrm{n}_{\mathrm{E}}$, where: $\mathrm{n}_{\mathrm{E}}=10$ - number of experts. Thus, the final weights of the individual criteria are: $\mathrm{w}_{1}=0.330 ; \mathrm{w}_{2}=0.295 ; \mathrm{w}_{3}=0.135 ; \mathrm{w}_{4}=0.135 ; \mathrm{w}_{5}=0.105$. Here: $w_{j}=1$, where: $j$ is the ordinal number of criteria, $j=1,2, \ldots, n$. It is noted that the experts appreciated the first two criteria more, which was expected.

Table 6: Criteria weights (all experts individually and average)

\begin{tabular}{|c|c|c|c|c|c|}
\hline \multirow{2}{*}{ Experts } & \multicolumn{5}{|c|}{ Criteria } \\
\cline { 2 - 6 } & $\begin{array}{c}\mathrm{f}_{1}- \\
\text { Effects }\end{array}$ & $\begin{array}{c}\mathrm{f}_{2}- \\
\text { Costs }\end{array}$ & $\begin{array}{c}\mathrm{f}_{3}- \\
\text { Consumers }\end{array}$ & $\begin{array}{c}\mathrm{f}_{4}- \\
\text { Competition }\end{array}$ & $\begin{array}{c}\mathrm{f}_{5} \text { - Hum. } \\
\text { resources }\end{array}$ \\
\hline Expert 1 & 0.3 & 0.3 & 0.15 & 0.15 & 0.1 \\
\hline Expert 2 & 0.4 & 0.3 & 0.1 & 0.1 & 0.1 \\
\hline Expert 3 & 0.3 & 0.3 & 0.2 & 0.1 & 0.1 \\
\hline Expert 4 & 0.35 & 0.35 & 0.1 & 0.1 & 0.1 \\
\hline Expert 5 & 0.3 & 0.4 & 0.1 & 0.1 & 0.1 \\
\hline Expert 6 & 0.4 & 0.2 & 0.1 & 0.2 & 0.1 \\
\hline Expert 7 & 0.3 & 0.25 & 0.2 & 0.2 & 0.05 \\
\hline Expert 8 & 0.25 & 0.25 & 0.2 & 0.2 & 0.1 \\
\hline Expert 9 & 0.3 & 0.3 & 0.1 & 0.1 & 0.2 \\
\hline Expert 10 & 0.4 & 0.3 & 0.1 & 0.1 & 0.1 \\
\hline$\Sigma / \mathrm{n}_{\mathrm{E}}$ & 0.330 & 0.295 & 0.135 & 0.135 & 0.105 \\
\hline
\end{tabular}

Source: the authors' research

\subsection{Multicriteria analysis problem solving - VIKOR method}

Each column of Table 5 (within each criterion) contains the maximum and minimum values, which are given in Table 7 . For the criteria with the minimum requirement $\left(\mathrm{f}_{2}\right.$ and $f_{5}$ ), the smallest value is the best and the lowest is the highest value. In this way, the criteria with the minimum requirement are translated into the criteria with the maximum requirement, in the VIKOR method.

Table 7: Best and worst stock values for all criteria

\begin{tabular}{|c|c|c|c|c|c|}
\hline & $\mathrm{f}_{1}$ & $\mathrm{f}_{2}$ & $\mathrm{f}_{3}$ & $\mathrm{f}_{4}$ & $\mathrm{f}_{5}$ \\
\hline $\mathrm{f}_{\mathrm{j}}^{*}$ & 0.86 & 0.28 & 0.86 & 0.72 & 0.32 \\
\hline $\mathrm{f}_{\mathrm{j}}^{-}$ & 0.26 & 0.80 & 0.30 & 0.34 & 0.76 \\
\hline
\end{tabular}

Source: the authors' research

For simpler calculation, the size $\mathrm{d}$ is introduced:

$\mathrm{d}_{\mathrm{ij}}=\frac{\mathrm{f}_{\mathrm{j}}^{*}-\mathrm{f}_{\mathrm{ij}}}{\mathrm{f}_{\mathrm{j}}^{*}-\mathrm{f}_{\mathrm{j}}^{-}}$

Table 8 gives the calculated values for $d_{i j}, w_{j} \cdot d_{i j}, S_{i} i R_{i}$. Examples of calculating some values in Table 8: 
$\mathrm{d}_{11}=\frac{0,86-0,86}{0,86-0,26}=0$

$\mathrm{d}_{21}=\frac{0,86-0,48}{0,86-0,26}=0,6333$

$\mathrm{w}_{1} \cdot \mathrm{d}_{11}=0.330 \cdot 0=0$

$\mathrm{w}_{1} \cdot \mathrm{d}_{21}=0.330 \cdot 0.6333=0.2090$
; $\quad \mathrm{d}_{12}=\frac{0,28-0,80}{0,28-0,80}=1$

; $\quad \mathrm{d}_{22}=\frac{0,28-0,58}{0,28-0,80}=0,5769$

$; \quad \mathrm{w}_{2} \cdot \mathrm{d}_{12}=0.295 \cdot 1=0.2950$

$; \quad \mathrm{W}_{2} \cdot \mathrm{d}_{22}=0.295 \cdot 0.5769=0.1702$

$\mathrm{S}_{1}=\sum_{\mathrm{j}=1}^{\mathrm{n}} \mathrm{w}_{\mathrm{j}} \cdot \mathrm{d}_{1 \mathrm{j}}=0+0,2950+0+0+0,0477=0,3427$

$\mathrm{S}_{2}=\sum_{\mathrm{j}=1}^{\mathrm{n}} \mathrm{w}_{\mathrm{j}} \cdot \mathrm{d}_{2 \mathrm{j}}=0,2090+0,1702+0,1157+0,0782+0,1050=0,6781$

$\mathrm{R}_{1}=\max _{\mathrm{j}} \mathrm{w}_{\mathrm{j}} \cdot \mathrm{d}_{1 \mathrm{j}}=\max (0 ; 0,2950 ; 0 ; 0 ; 0,0477)=0,2950$

$\mathrm{R}_{2}=\max _{\mathrm{j}} \mathrm{w}_{\mathrm{j}} \cdot \mathrm{d}_{2 \mathrm{j}}=\max (0,2090 ; 0,1702 ; 0,1157 ; 0,0782 ; 0,1050)=0,2090$

Table 8: Calculated values for dij, wj $\times$ dij, Si and Ri

\begin{tabular}{|c|c|c|c|c|c|c|c|c|c|c|c|c|}
\hline \multirow{2}{*}{$\begin{array}{c}\text { Actions } \\
\mathrm{a}_{\mathrm{i}}\end{array}$} & \multicolumn{9}{|c|}{$\mathrm{d}_{\mathrm{ij}}$} & \multicolumn{5}{c|}{$\mathrm{w}_{\mathrm{j}} \cdot \mathrm{d}_{\mathrm{ij}}$} & \multirow{2}{*}{$\mathrm{S}_{\mathrm{i}}$} & \multirow{2}{*}{$\mathrm{R}_{\mathrm{i}}$} \\
\cline { 2 - 13 } & $\mathrm{f}_{1}$ & $\mathrm{f}_{2}$ & $\mathrm{f}_{3}$ & $\mathrm{f}_{4}$ & $\mathrm{f}_{5}$ & $\mathrm{f}_{1}$ & $\mathrm{f}_{2}$ & $\mathrm{f}_{3}$ & $\mathrm{f}_{4}$ & $\mathrm{f}_{5}$ & & \\
\hline $\mathrm{a}_{1}$ & 0 & 1 & 0 & 0 & 0.4545 & 0 & 0.2950 & 0 & 0 & 0.0477 & 0.3427 & 0.2950 \\
\hline $\mathrm{a}_{2}$ & 0.6333 & 0.5769 & 0.8571 & 0.5789 & 1 & 0.2090 & 0.1702 & 0.1157 & 0.0782 & 0.1050 & 0.6781 & 0.2090 \\
\hline $\mathrm{a}_{3}$ & 0.4000 & 0.1923 & 0.6786 & 1 & 0.8636 & 0.1320 & 0.0567 & 0.0916 & 0.1350 & 0.0907 & 0.5060 & 0.1350 \\
\hline $\mathrm{a}_{4}$ & 0.5667 & 0 & 0.3571 & 0.4737 & 0 & 0.1870 & 0 & 0.0482 & 0.0639 & 0 & 0.2991 & 0.1870 \\
\hline $\mathrm{a}_{5}$ & 0.6667 & 0.6923 & 0.7143 & 0.2632 & 0.2727 & 0.2200 & 0.2042 & 0.0964 & 0.0355 & 0.0286 & 0.5847 & 0.2200 \\
\hline $\mathrm{a}_{6}$ & 1 & 0.1538 & 1 & 0.1579 & 0.5909 & 0.3300 & 0.0454 & 0.1350 & 0.0213 & 0.0620 & 0.5937 & 0.3300 \\
\hline
\end{tabular}

Source: the authors' research

From the last two columns of Table 8 , the values required for the further budget are read: $\mathrm{S}^{*}=0.2991 ; \mathrm{S}^{-}=0.6781 ; \mathrm{R}^{*}=0.1350 ; \mathrm{R}^{-}=0.3300$. Table 9 gives the calculated values for $\mathrm{QS}_{\mathrm{i}}, \mathrm{QR}_{\mathrm{i}}, \mathrm{Q}_{\mathrm{i}}(\mathrm{v}=0.5), \mathrm{Q}_{\mathrm{i}}(\mathrm{v}=0.25)$ and $\mathrm{Q}_{\mathrm{i}}(\mathrm{v}=0.75)$. Examples of calculating some values in Table 9:

$$
\begin{aligned}
& Q S_{1}=\frac{S_{1}-S^{*}}{S^{-}-S^{*}}=\frac{0.3427-0.2991}{0.6781-0.2991}=0.1150 \\
& Q S_{2}=\frac{S_{2}-S^{*}}{S^{-}-S^{*}}=\frac{0.6781-0.2991}{0.6781-0.2991}=1 \\
& Q R_{1}=\frac{R_{1}-R^{*}}{R^{-}-R^{*}}=\frac{0.2950-0.1350}{0.3300-0.1350}=0.8205
\end{aligned}
$$




$$
\begin{aligned}
& Q R_{2}=\frac{R_{2}-R^{*}}{R^{-}-R^{*}}=\frac{0.2090-0.1350}{0.3300-0.1350}=0.3795 \\
& \mathrm{Q}_{1(\mathrm{v}=0.5)}=\mathrm{v} \cdot \mathrm{QS}_{1}+(1-\mathrm{v}) \cdot \mathrm{QR}_{1}=0.5 \cdot 0.1150+(1-0.5) \cdot 0.8205=0.4678 \\
& \mathrm{Q}_{2(\mathrm{v}=0.5)}=\mathrm{v} \cdot \mathrm{QS}_{2}+(1-\mathrm{v}) \cdot \mathrm{QR}_{2}=0.5 \cdot 1+(1-0.5) \cdot 0.3795=0.6897 \\
& \mathrm{Q}_{1(\mathrm{v}=0.25)}=\mathrm{v} \cdot \mathrm{QS}_{1}+(1-\mathrm{v}) \cdot \mathrm{QR}_{1}=0.25 \cdot 0.1150+(1-0.25) \cdot 0.8205=0.6475 \\
& \mathrm{Q}_{2(\mathrm{v}=0.25)}=\mathrm{v} \cdot \mathrm{QS}_{2}+(1-\mathrm{v}) \cdot \mathrm{QR}_{2}=0.25 \cdot 1+(1-0.25) \cdot 0.3795=0.5346 \\
& \mathrm{Q}_{1(\mathrm{v}=0.75)}=\mathrm{v} \cdot \mathrm{QS}_{1}+(1-\mathrm{v}) \cdot \mathrm{QR}_{1}=0.75 \cdot 0.1150+(1-0.75) \cdot 0.8205=0.2914 \\
& \mathrm{Q}_{2(\mathrm{v}=0.75)}=\mathrm{v} \cdot \mathrm{QS}_{2}+(1-\mathrm{v}) \cdot \mathrm{QR}_{2}=0.75 \cdot 1+(1-0.75) \cdot 0.3795=0.8449
\end{aligned}
$$

Table 9: Calculated values for $Q S i, Q R i, Q i(v=0.5), Q i(v=0.25)$ and $Q i(v=0.75)$

\begin{tabular}{|c|c|c|c|c|c|}
\hline $\mathrm{a}_{i}$ & $\mathbf{Q S}_{\mathbf{i}}$ & $\mathbf{Q R}_{\mathbf{i}}$ & $\mathbf{Q}_{\mathbf{i}}(\mathbf{v}=\mathbf{0 . 5})$ & $\mathrm{Q}_{\mathrm{i}}(\mathrm{v}=0.25)$ & $\mathrm{Q}_{\mathrm{i}}(\mathrm{v}=0.75)$ \\
\hline $\mathrm{a}_{1}$ & $\mathbf{0 . 1 1 5 0}$ & $\mathbf{0 . 8 2 0 5}$ & $\mathbf{0 . 4 6 7 8}$ & 0.6475 & 0.2914 \\
\hline $\mathrm{a}_{2}$ & $\mathbf{1}$ & $\mathbf{0 . 3 7 9 5}$ & $\mathbf{0 . 6 8 9 8}$ & 0.5346 & 0.8449 \\
\hline $\mathrm{a}_{3}$ & $\mathbf{0 . 5 4 5 9}$ & $\mathbf{0}$ & $\mathbf{0 . 2 7 3 0}$ & 0.1364 & 0.4094 \\
\hline $\mathrm{a}_{4}$ & $\mathbf{0}$ & $\mathbf{0 . 2 6 6 7}$ & $\mathbf{0 . 1 3 3 3}$ & 0.2000 & 0.0667 \\
\hline $\mathrm{a}_{5}$ & $\mathbf{0 . 7 5 3 6}$ & $\mathbf{0 . 4 3 5 9}$ & $\mathbf{0 . 5 9 4 8}$ & 0.5153 & 0.6742 \\
\hline $\mathrm{a}_{6}$ & $\mathbf{0 . 7 7 7 3}$ & $\mathbf{1}$ & $\mathbf{0 . 8 8 8 6}$ & 0.9444 & 0.8330 \\
\hline
\end{tabular}

Source: Authors research

The results from Table 9 can be presented graphically (Figure 1). In this figure, the ranking of individual actions can be visually observed, depending on the weight $\mathrm{v}$. According to the obtained QSi, QRi and Qi sizes for each action (Table 9 and Figure 1), three independent rank lists can be formed (Table 10). The QSi criterion is the best action $\mathrm{a}_{4}$, and the QRi criterion the best action $\mathrm{a}_{3}$. Overall, according to Qi $(\mathrm{v}=0.5)$, the best action is $\mathrm{a}_{4}$.

\section{Testing conditions U1:}

The threshold of "sufficient advantage" in a given case, for the number of actions $\mathrm{m}=6$ :

$\mathrm{DQ}=\min \left(0.25 ; \frac{1}{\mathrm{~m}-1}\right)=\min \left(0.25 ; \frac{1}{6-1}\right)=0.2$

Analysis of the next action (second in rank - action $\mathrm{a}_{3}$ ):

$\mathrm{Q}\left(\mathrm{a}_{3}\right)-\mathrm{Q}\left(\mathrm{a}_{4}\right)=0.2730-0.1333=0.1397<\mathrm{DQ}=0.2$

Condition U1 is not fulfilled here. Action $\mathrm{a}_{3}$ enters a set of compromise solutions, since the first action $\mathrm{a}_{4}$ does not have a "sufficient advantage" over the second ranked action $\mathrm{a}_{3}$. Next action analysis ( $3 \mathrm{rd}$ in rank - action $\mathrm{a}_{1}$ ):

$\mathrm{Q}\left(\mathrm{a}_{1}\right)-\mathrm{Q}\left(\mathrm{a}_{4}\right)=0.4678-0.1333=0.3345>\mathrm{DQ}=0.2$ 
Here condition U1 is fulfilled. Action a does not fall into the set of compromise solutions, since the first action $\mathrm{a}_{4}$ has a "sufficient advantage" over the third ranked action $\mathrm{a}_{1}$. Other actions need not be further tested under this condition.

Testing conditions U2:

Condition $\mathrm{U} 2$ is fulfilled since action $\mathrm{a}_{4}$ has the first position in the ranking list and according to the QS criterion. Thus, under condition U2, action a $\mathrm{a}_{4}$ has a "stable enough" first place.

Figure 1: Rank of individual actions depending on weight $v$

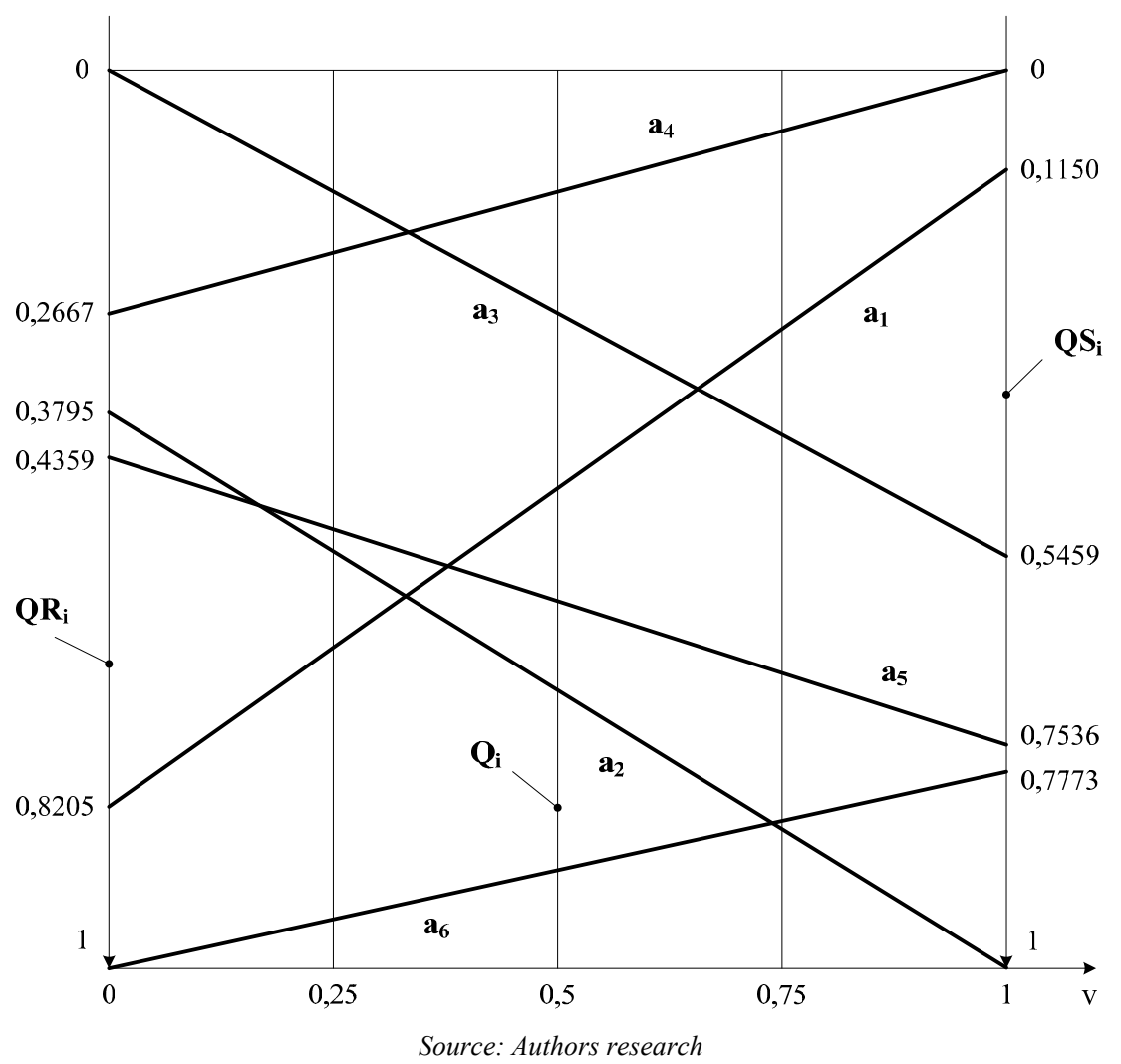


Table 10: Rank list based on sizes QSi, QRi i Qi

\begin{tabular}{|c|c|c|c|}
\hline $\mathrm{a}_{\mathrm{i}}$ & $\mathrm{QS}_{\mathrm{i}}$ & $\mathrm{QR}_{\mathrm{i}}$ & $\mathbf{Q}_{\mathbf{i}}(\mathbf{v}=\mathbf{0 . 5})$ \\
\hline $\mathrm{a}_{1}$ & 2 & 5 & $\mathbf{3}$ \\
\hline $\mathrm{a}_{2}$ & 6 & 3 & $\mathbf{5}$ \\
\hline $\mathrm{a}_{3}$ & 3 & 1 & $\mathbf{2}$ \\
\hline $\mathrm{a}_{4}$ & 1 & 2 & $\mathbf{1}$ \\
\hline $\mathrm{a}_{5}$ & 4 & 4 & $\mathbf{4}$ \\
\hline $\mathrm{a}_{6}$ & 5 & 6 & $\mathbf{6}$ \\
\hline
\end{tabular}

Source: Authors research

The final solution is defined by a set of compromise solutions that include actions $\mathbf{a}_{4}$ and $\mathbf{a}_{3}$.

\section{Discussion of results}

Using the VIKOR method, a set of compromise solutions was defined for a given problem of multicriteria analysis: the choice of the form of promotion of a particular product group. This set included the following actions: $a_{4}$ - Publicity and $a_{3}$ - Sales promotion. In general, publicity has come first, owing in large part to the low costs it requires, but also to the very good potential effects. The problem is that publicity is not such a reliable form of promotion: it sometimes exists and then it should certainly be exploited to the maximum, but sometimes it simply is not sufficiently present.

This makes it a significant second in the stock rankings, which is Sales promotion. If Publicity is accepted as the best action, if any, then Sales promotion, in this case, can be conditionally regarded as a first-rate action. Then the importance of the next rank of actions, which is $\mathrm{a}_{1}$ - Economic propaganda, becomes important. For these reasons, it is useful to check condition U1 between actions $a_{3}$ - Sales promotion and $\mathrm{a}_{1}$ - Commercial propaganda:

$\mathrm{Q}\left(\mathrm{a}_{1}\right)-\mathrm{Q}\left(\mathrm{a}_{3}\right)=0.4678-0.2730=0.1948<\mathrm{DQ}=0.2$

Condition U1 is not met because action $a_{3}$ does not have a "sufficient advantage" over action $\mathrm{a}_{1}$. So, action $\mathrm{a}_{1}$ - Economic propaganda can be found in a set of compromise solutions. Practically, in a given situation, where the presence of the first ranked action is often uncertain, the set of compromise solutions is adjusted in the direction of expansion. Undoubtedly, economic propaganda brings significant effects, but also the greatest costs.

A limitation of the research is that the example presented is unique, that is, it is valid for the analyzed situation of choosing a form of promotion. In some other conditions (another company, another product/service group, and environmental conditions), the results may be the same, similar, but quite different. 


\section{Conclusion}

The application of the expert method contributed to the increased objectivity in the process of forming the initial decision matrix (Table 5), as well as in the procedure for determining the weights of criteria in the model (Table 6). Also, the VIKOR method proved to be very suitable for solving the analyzed problem. First, because it maximally respected the initial data obtained by the expert method: it was these data that went directly into the further calculation, which from that point was precise and completely objective. Another advantage of the VIKOR method is the ability to form a set of compromise solutions, which proved to be very useful in this case. The final conclusion and recommendation for the marketing department of the observed company is the following: in the promotion of the analyzed products group, publicity should be maximized if it exists, economic propaganda should be applied in accordance with financial possibilities, and most attention and energy should be directed towards sales promotion activities.

\section{References}

Caffi, T., Helsen, H.H.M., Rossi, V., Holb, I.J., Strassemeyer, J., Buurma, J.S., Capowiez, Y., Simon, S., \& Alaphilippe, A. (2017). Multicriteria evaluation of innovative IPM systems in pome fruit in Europe. Crop Protection, 97, 101-108. Doi: https://doi.org/10.1016/j.cropro.2016.12.009

Craheix, D., Angevin, F., Doré, T., \& de Tourdonnet, S. (2016). Using a multicriteria assessment model to evaluate the sustainability of conservation agriculture at the cropping system level in France. European Journal of Agronomy, 76, 75-86. Doi: https://doi.org/10.1016/j.eja.2016.02.002

Čupić, M., Tummala, R., \& Suknović, M. (2001). Odlučivanje: formalni pristup. Beograd: Fakultet organizacionih nauka.

Dufner, D., Hiltz, R.S., Johnson, K., \& Czech, R. (1995). Distributed Group Support: The Effects of Voting Tools on Group Perceptions of Media Richness. Group Decision and Negotiation, 4(3), 235-250. Doi: https://doi.org/10.1007/BF01384690

Đorđević, D., \& Ćoćkalo, D. (2004). Osnove marketinga. Zrenjanin: Tehnički fakultet "Mihajlo Pupin".

Gordon, A.E. (2011). Public Relations. Oxford, New York: Oxford University Press.

Grunig, J.E., (Ed.), (1992). Excellence in Public Relations and Communnication Management. Hillsdale, New Jersey: Lawrence Erlbaum Association.

Hernandez-Perdomo, E.A., Mun, J., \& Rocco C.M.S. (2017). Active management in state-owned energy companies: Integrating a real options approach into multicriteria 
analysis to make companies sustainable. Applied Energy, 195, 487-502. Doi: https://doi.org/10.1016/j.apenergy.2017.03.068

Kotler, Ph., Kartajaya, H., \& Setiawan, I. (2017). Marketing 4.0 - Moving from Traditional to Digital. Hoboken: John Willey \& Sons, Inc.

Kotler, P., \& Armstrong, G. (1996). Principles of Marketing. Englewood Cliffs, New Jersey: Prentice Hall International Editions.

Martínez-Sastre, R., Ravera, F., González, J.A., López Santiago, C., Bidegain, I., \& Munda, G. (2017). Mediterranean landscapes under change: Combining social multicriteria evaluation and the ecosystem services framework for land use planning. Land Use Policy, 67, 472-486. Doi: https://doi.org/10.1016/j.landusepol.2017.06.001

Milisavljević, M. (2001). Marketing. Beograd: Savremena administracija.

Muangkhot, S., \& Ussahawanitchakit, P. (2015). Strategic marketing innovation and marketing performance: An empirical investigation of furniture exporting businesses in Thailand. The Business and Management Review, 7(1), 189-205.

Müller, J.M., \& Däschle, S. (2018). Business Model Innovation of Industry 4.0 Solution Providers towards Customer Process Innovation. Processes, 6(12), 260. Doi: https://doi.org/10.3390/pr6120260

Nikolić, M. (2012a). Metode odlučivanja II izdanje. Zrenjanin: Tehnički fakultet "Mihajlo Pupin".

Nikolić, M. (2012b). Odnosi s javnošću. Zrenjanin: Tehnički fakultet "Mihajlo Pupin”.

Opricović, S. (1986). Višekriterijumska optimizacija. Beograd: Naučna knjiga.

Opricović, S., \& Tzeng, G.H. (2004). The Compromise solution by MCDM methods: A comparative analysis of VIKOR and TOPSIS. European Journal of Operational Research, 156(2), 445-455. Doi: https://doi.org/10.1016/S0377-2217(03)00020-1

Prahalad, C.K., \& Ramaswamy, V. (2004). Co-creation experiences: The next practice in value creation. Journal of Interactive Marketing, 18(3), 5-14. Doi:

https://doi.org/10.1002/dir.20015

Radojičić, M., \& Žižović, M. (1998). Primena metoda višekriterijumske analize u poslovnom odlučivanju. Čačak: Tehnički fakultet.

Raj, A., Kumar, A.J., \& Bansal, P. (2020). A multicriteria decision making approach to study barriers to the adoption of autonomous vehicles. Transportation Research Part A: Policy and Practice, 133, 122-137. Doi: https://doi.org/10.1016/j.tra.2020.01.013 
Ribera, F., Nesticò, A., Cucco, P., \& Maselli, G. (2020). A multicriteria approach to identify the Highest and Best Use for historical buildings. Journal of Cultural Heritage, 41, 166-177. Doi: https://doi.org/10.1016/j.culher.2019.06.004

Romeo, G., \& Marcianò, C. (2019). Evaluating the economic performance of fishing systems using fuzzy multicriteria analysis in a Fishery Local Action Group in South Italy. Fisheries Research, 218, 259-268. Doi: https://doi.org/10.1016/j.fishres.2019.05.015

Sala, H., \& Trivín, P. (2018). The effects of globalization and technology on the elasticity of substitution. Review of World Economics, 154(3), 617-647. Doi: https://doi.org/10.1007/s10290-018-0315-7

Schlechtendahl, J., Keinert, M., Kretschmer, F., Lechler, A., \& Verl, A. (2015). Making existing production systems Industry 4.0-ready. Production Engineering, 9(1), 143-148. Doi: https://doi.org/10.1007/s11740-014-0586-3

Son, J., Sadachar, A., Manchiraju, S., Fiore, A.M., \& Niehm, L.S. (2012). Consumer adoption of online collaborative customer co-design. Journal of Research in Interactive Marketing, 6(3), 180-197. Doi: https://doi.org/10.1108/17505931211274660

Wilcox, D.L., \& Cameron, G.T. (2009). Public Relations (9th ed.). Boston: Allyn \& Bacon.

Wollschlaeger, M., Sauter, T., \& Jasperneite, J. (2017). The future of industrial communication: Automation networks in the era of the internet of things and industry 4.0. IEEE Industrial Electronics Magazine, 11(1), 17-27. Doi:

https://doi.org/10.1109/MIE.2017.2649104 